\title{
Looking at Stratification in Education Through a Modern Day Prism
}

\author{
Ralph Gallo \\ Texas Southern University, Administration of Justice \\ Mickey Leland - Barbara Jordan School of Public Affairs \\ 3100 Cleburne, Houston, TX 77004
}

\begin{abstract}
The purpose of this research is to investigate the perception of community members' family status and its impact on education, personal wealth, income, job opportunities, generational inequality, illiteracy, technology, free or reduced lunchprogram, and child's attendance at a high poverty school. These implications will be discussed through the theoretical perspectives of Max Weber's Theory of Stratification. A survey design was used to collect and analyze the data. Two hundred twenty two participants elected to participate in this study. The results revealed that there were statistically significant differences between community members' family status and income level. Furthermore, there were statistically significant differences between the community members' education level and their association with a friend or relative with a criminal background.
\end{abstract}

Key Words: Social Stratification, Inequality, Resource Distribution, Theory of Stratification

\section{INTRODUCTION}

The purpose of this research is to investigate the perception of community members' social status within the stratification system and its impact on income, level of education, health, generational inequality, access to educational resources and community viability. The phenomena will be investigated through the theoretical perspective of division of labor and Theory of Stratification. The division of labor sheds light on the clear delineation of wealthby grouping individuals as haves and have nots. The theory of stratification further expands on the division of the classes by wealth to include one's social status, power and class as defined by Max Weber as the upper class, white-collar workers, middle class, and the manual working class. The educational system has faced many challenges throughout history, many of which still plague it today. A persistent challenge that school districts face nationwide are related to how school are funded and the types of resources available to the students they serve. The growing problem is that all schools are not funded equally even though they may share the same school district. In fact, schools are almost guaranteed to be funded differently based on the tax revenues generated in a given region of the district. Communities with a concentration of low socioeconomic status are more likely to have the largest population of students eligible free or reduced school lunch. Most notably, areas that have an economically challenged tax base tend to be economically challenged in educational resources as well, doubly compounding the problem. The resulting problem presents itself as inequality in distributing resources and funding across the district.

\section{Theoretical Perspective of Social Inequality}

No other theorist continues to be as relevant to classism and social inequality as Karl Marx and Max Weber and their description of wealth and separation of the classes. Marx's work on the 
separation of the classes and the division of labor was the foundation that classism and socioeconomic status would be understood: a division of the haves (wealthier class) and the have nots (poor working class). Weber was most notably known for his contribution of theory on the difficulty of upward mobility. There is no denying that even now the global society is still struggling with social inequality and oppression of the lower classes. This striking argument was posed in the mid-1800s and resonates as though it was proposed just yesterday. Likewise, there also is a startling similarity of the struggle of gender and racial inequality. Belkheir, et al. (1994) noted that there is a distinctive intersection between race, sex and class dynamics that is inseparable.

While racism is certainly a contemporary sociological phenomenon, Weber was ahead of his time in agreeing with W.E.B. Dubois assertion that the problem of the 20th century will be one along color lines. However, heagreed with Marx by primarilyfocusing on classism, division of the wealth into the haves and the have nots, and the suppression of the poor lower classes for the betterment of the wealthier upper classes. Where there was a major difference was the subtle attention paid to race and ethnicity. In discussing this intersection of race and class, Willheim (1970, 1983) states that while it is connected to social inequality, it "is an independent cause for...continued oppression" (p. 65). Willheim posits that racism cannot be reduced to a byproduct of capitalism. Paralleling these findings are those of George (2006) who stated that the groups historically facing discrimination has improved while "the overall economic situation of the nation's lower half has worsened" (p. 429). Most striking is that gains of sixty-five percent and sixty percent for African American and white women respectively still has not erased inequality of earnings between men and women. George proposes that the gap in the lower socioeconomic levels from their upper level counterparts can be attributed to desegregation and African Americans with greater skill sets were more likely to move out of low-income neighborhoods leaving behind less skilled individuals. He proposed that as individuals exit lower levels and enter higher levels of socioeconomic status, someone takes their place in the lower levels. Nadrag and Nadrag (2014) posit that there are four major stratification systems: slavery, caste, estate, and class. While many different countries use one the first three forms of stratification, the U.S. uses a class system that is defined by economic stratification. Class membership is not defined by law or custom as with estates defined by obligation and rights. Instead, it is more fluid where the boundaries between the classes are not clear. Inequality occurs when one or more classes have greater access to resources and wealth over the other classes. Rekker, et al. (2016) indicate that low socioeconomic status families are more likely to live in poor and unstable neighborhoods. These neighborhoods, in turn, are less likely to have a strong enough tax base to support the growing needs of the schools in its districts.

\section{Still Separate, Still Unequal}

A historical examination of education in this country would not be complete without discussing the disparities of race and class. These forms of disparities date back as far as the Civil War, if not before. Education was considered a privilege in this country, not a right.In most cases,it was reserved for privileged whites and their children. The ideal of equality in education is still somewhat ambiguous and vague even today. Let history remind us that no matter what level of government we discus (federal, state, and local government)there will be someform of disparity that was promoted against the poor and people of color. History also reminds us that public education did not come to the south until after the Civil War. It was also a well noted fact that while African Americans were denied the right to a quality education, poor whites were as well. After the Civil War and during the reconstruction period, the south was ordered to develop a public education system. This idea of having a public education system that served African Americans and poor whites right along with privileged whites was not something that 
set well with the status quo. During this time, that states were responsible for their own funding. However, not all groups were funded the same.It was done internally and intentionally by elite whites.

The majority of public school funding comes from a local tax base; by that definition alone, not all tax bases are created equal. This concept is still relevant even today. Schools belonging to the same school district but located in different areas of the district does not guarantee that they all will receive the same funding and resources. Consequently, the amount will vary due to the amount of tax revenues generated in that specific area. That means that one school could rival a university based on the types of accessible resources available to them. A perfect example is the form and level of technology a school has at its disposal i.e. computers, smart boards, laptops, tablets, computer labs, technology training, etc. However, in that same school district you have a school that seems to be in a third world country because of how it is funded. There has also been a lengthy discussion on weather a school environment has more of an impact on a student than their intellectual abilities and family.Kozal(1991) indicated how recourses were applied unequally.He posits that regardless of a person's intellectual abilities or family, their educational environment can indeed impact the student if they do not receive the same resources as privileged students. He also discussed racial disparities as related to the structure of funding and division of resources. Moreover, Kozol(2012) examined the south and what privileged whites would do to keep their children from a school that had African American students. They would put their children in private schools, and in the north, they would remove their children from inner city schools and enroll them in suburban schools where quality resources were much more available. While these strategies may seem new, they date all the way back to the Reconstruction Era. Many elite whiteswanted to maintain the separate but equal split, but blacks had earned the right to vote and challenged the status quo. However, as soon as federal troops were removed from the south during integration, it became business as usual where white elitists were able to regain their political positions by ultimately undoing what little progress had been made. We should also be reminded as we picture the south as being unjust to blacks that the north was filled with individuals who embraced the south's belief.

Even with the historical win of Brown v. The Board of Education,there were many states who were not complying with newly established laws of the land. However, there was new legislation enacted that eventually bought about the change that many were seeking:the first being the Civil Rights Act of 1964 and then the Elementary and Secondary Actof 1965. What made these two pieces of legislation so powerful is that both had teeth with an establishment of an enforceable penalty for failing to follow the court's ruling. The Civil Rights Act made it illegal for anyone to discriminate against another individual based on their color. If the federal government found this to be so, they could withhold any federal funding. The second was the Elementary and Secondary Education was also responsible for funding elementary and secondary schools and whenever stateswere not in compliance those resources that they would normally receive would be held until they complied with federal guidelines.

\section{METHODOLOGY}

A survey design was used to collect and analyze the data. Two hundred thirty eight out of three hundred participants elected to participate in this study. The instrument entitled "Gallo-Amos Community Perception Instrument" was used to collect the data. The data was used to examine education level and its impact on income, criminal background and one's agreement with the 
necessity of education programs within the prison system. The One-Way Analysis of Variance and the Scheffé Multiple Comparison Test were used to analyze the data.

\section{RESULTS}

A survey design was used to collect and analyze the data. Two hundred and twenty out of four hundred participants elected to participate in this study. The instrument entitled "Gallo-Amos Community Perception Instrument" was used to collect the data. The data was used to examine family status and its impact on education, personal wealth, income, job opportunities, generational inequality, illiteracy, technology, free or reduced lunch program, and whether their child attends a high poverty school. The One-Way Analysis of Variance and the Scheffé Multiple Comparison Test were used to analyze the data.

The descriptive statistics of the participants revealed there were one hundred fourteen (51\%) male participants and one hundred six (48\%) female participants. The racial demographics revealed that while there were five categories to choose from, only three were selected. One hundred twelve (51\%) participants identified themselves as African American, eighty (36\%) Hispanic and twenty eight (13\%) white. Similarly, age has seven categories, however, the participants self-reported age in four categories. There were thirty six (16\%) participants who were between the ages of twenty and thirty; one hundred nine (50\%) were between thirty one and forty. In addition, forty- three (19\%) participants reported their age as forty one through fifty, and thirty two (15\%) said they were fifty one through sixty.

Regarding the participants' level of education, one individual reported having less than a high school education (.5\%), fifteen (6.8\%) reported graduating from high school or earning a GED and thirty two $(14.5 \%)$ had some college. On the other hand, ninety seven $(44.1 \%)$ participants completed their associate's degree, forty six (20.9\%) said they completed their bachelor's degree and twenty nine $(13.2 \%)$ reported earning their master's degree. Relative to the annual incomes of the participants, fifty one $(23.2 \%)$ of them reported their incomes less than $\$ 20,000$, and sixty six (30\%) revealed their income as being between $\$ 20,000$ and $\$ 30,000$. Additionally, fifty six (25.5\%) participants identified their income as $\$ 31,000$ to $\$ 40,000$, thirty three $(15 \%)$ indicated their income was $\$ 41,000$ to $\$ 50,000$ and fourteen $(6.4 \%)$ reported their income over $\$ 51,000$.

Table 1:Analysis of Variance Summary Table of the Impact of Personal Wealth on Family Status

\begin{tabular}{|c|c|c|c|c|c|c|}
\hline & Source of Variance & Sum of Squares & $d f$ & Mean Square & $\mathbf{F}$ & Sig. \\
\hline & Between Groups & 57.211 & 4 & 14.303 & 8.856 & .000 \\
\hline Personal Wealth & Within Groups & 347.239 & 215 & 1.615 & & \\
\hline & Total & 404.450 & 219 & & & \\
\hline
\end{tabular}

*Significant at the .05 Level

Table 2: Scheffé Results of Personal Wealth by Family Status

\begin{tabular}{|c|c|c|c|c|c|c|}
\hline $\begin{array}{r}\text { Mean 1 } \\
\text { (Poor) }\end{array}$ & $\begin{array}{c}\text { Mean } 2 \\
\text { (Working Class) }\end{array}$ & $\begin{array}{c}\text { Mean } 3 \\
\text { (Middle Class) }\end{array}$ & $\begin{array}{c}\text { Mean } 4 \\
\text { (White Collar } \\
\text { Worker) }\end{array}$ & $\begin{array}{c}\text { Mean } 5 \\
\text { (Upper Class) }\end{array}$ & $\begin{array}{c}\text { Observed Mean } \\
\text { Differences }\end{array}$ & p \\
\hline 3.39 & 3.45 & & & & -.062 & .999 \\
\hline 3.39 & & 2.80 & & & .589 & .225 \\
\hline 3.39 & & & 4.39 & & $-1.002 *$ & $.016^{*}$ \\
\hline 3.39 & & & & 4.00 & -.608 & .643 \\
\hline
\end{tabular}

Presented in Table 1 are the Analysis of Variance results pertaining to the perceptions of community members regarding the impact of family status on personal wealth of the 
participants. As revealed in this table, statistically significant differences were found among the community members with regard to family status $(F=8.856, \mathrm{df}=4 / 219, \mathrm{p}>.05)$ at the .05 level. Since the Analysis of Variance indicated significance but did not reveal where the differences were, the Scheffé Test was used. Further data analysis using the Scheffé Multiple Comparison Test revealed that the community residents' family status as having been effective in increasing personal wealth for those who identify themselves as white collar (See Table 2).

Table 3: Analysis of Variance Summary Table of the Impact of Income on Family Status

\begin{tabular}{ccrrrrr}
\hline & Source of Variance & Sum of Squares & df & Mean Square & F & Sig. \\
\hline \multirow{2}{*}{ Income } & Between Groups & 94.571 & 4 & 23.643 & 32.248 & $.000^{*}$ \\
& Within Groups & 157.629 & 215 & .733 & & \\
\hline
\end{tabular}

*Significant at the .05 Level

Table 5: Analysis of Variance Summary Table of the Impact of Education on Family Status

\begin{tabular}{ccrrrrr}
\hline & Source of Variance & Sum of Squares & df & Mean Square & F & Sig. \\
\hline \multirow{2}{*}{ Education } & Between Groups & 123.453 & 4 & 30.863 & 50.030 & .000 \\
& Within Groups & 132.633 & 215 & .617 & \\
\hline
\end{tabular}

*Significant at the .05 Level

Presented in Table 3are the Analysis of Variance results pertaining to the perceptions of community members regarding the impact of family status on income of the participants. As revealed in this table, statistically significant differences were found among the community members with regard to family status $(F=32.248, \mathrm{df}=4 / 219, \mathrm{p}>.05)$ at the .05 level. Running the Scheffé (Table 4) revealed that community residents who identified themselves as being upper class upper class perceived their family status impacted their level of income more than their poor, working class, middle class and white collar counterparts. No other mean differences were found.

Analysis of Variance (henceforth called ANOVA) results reveal that there was a significant difference among the groups related to the impact of education as it relates to family status. Table 5 indicates that statistically significant differences were found among the community members with regard to family status $(\mathrm{F}=32.248, \mathrm{df}=4 / 219, \mathrm{p}>.05)$ at the .05 level. Scheffé Multiple Comparison Test (Table 6) indicated that all community residents regardless of status indicated that they perceived their family status impacted their level of education.

Table 6: Scheffé Results of Education by Family Status

\begin{tabular}{ccccccc}
\hline $\begin{array}{c}\text { Mean 1 } \\
\text { (Poor) }\end{array}$ & $\begin{array}{c}\text { Mean 2 } \\
\text { (Working Class) }\end{array}$ & $\begin{array}{c}\text { Mean 3 } \\
\text { (Middle Class) }\end{array}$ & $\begin{array}{c}\text { Mean 4 } \\
\text { (White Collar } \\
\text { Worker) }\end{array}$ & $\begin{array}{c}\text { Mean 5 } \\
\text { (Upper Class) }\end{array}$ & $\begin{array}{c}\text { Observed Mean } \\
\text { Differences }\end{array}$ & p \\
\hline 3.12 & 3.88 & & & & -.761 & $.000^{*}$ \\
3.12 & & 5.02 & & & -1.900 & $.000^{*}$ \\
3.12 & & & 4.97 & 4.21 & -1.052 & $.000^{*}$ \\
3.12 & & & & & $.000^{*}$ \\
\hline
\end{tabular}

Table 7: Analysis of Variance Summary Table of the Impact of Job Opportunities on Family Status

\begin{tabular}{ccrrrrl}
\hline & Source of Variance & Sum of Squares & df & Mean Square & F & Sig. \\
\hline \multirow{3}{*}{ Job Opportunities } & Between Groups & 23.028 & 4 & 5.757 & 5.164 & $.001^{*}$ \\
& Within Groups & 239.699 & 215 & 1.115 & & \\
\hline
\end{tabular}

*Significant at the .05 Level 
Table 8: Scheffé Results of Job Opportunities by Family Status

\begin{tabular}{ccccccc}
\hline $\begin{array}{c}\text { Mean 1 } \\
\text { (Poor) }\end{array}$ & $\begin{array}{c}\text { Mean 2 } \\
\text { (Working Class) }\end{array}$ & $\begin{array}{c}\text { Mean 3 } \\
\text { (Middle Class) }\end{array}$ & $\begin{array}{c}\text { Mean 4 } \\
\text { (White Collar } \\
\text { Worker) }\end{array}$ & $\begin{array}{c}\text { Mean 5 } \\
\text { (Upper Class) }\end{array}$ & $\begin{array}{c}\text { Observed Mean } \\
\text { Differences }\end{array}$ & p \\
\hline 3.75 & 4.02 & & & & -.270 & .757 \\
3.75 & & 4.45 & & & -719 & $.017 *$ \\
3.75 & & 4.48 & -.740 & .047 \\
3.75 & & & & 4.71 & -.969 & .059 \\
\hline
\end{tabular}

Table 9: Analysis of Variance Summary Table of the Impact of Generational Inequality on Family Status

\begin{tabular}{|c|c|c|c|c|c|c|}
\hline & Source of Variance & Sum of Squares & $d f$ & Mean Square & $\mathbf{F}$ & Sig. \\
\hline & Between Groups & 33.066 & 4 & 8.266 & 7.583 & $.000 *$ \\
\hline \multirow[t]{2}{*}{$\begin{array}{l}\text { Generational } \\
\text { Inequality }\end{array}$} & Within Groups & 234.371 & 215 & 1.090 & & \\
\hline & Total & 267.436 & 219 & & & \\
\hline
\end{tabular}

Likewise, ANOVA results reveal a significant difference among the means as regards to the impact of job opportunities on family status $(F=5.164, \mathrm{df}=4 / 219, \mathrm{p}>.05)$ at the .05 level. See Table 7 for these results. Table 8 shows that individuals that identify themselves as middle classperceive that their family status has impacted them being offered opportunities for jobs more than individuals who self-identified as poor, working class, white collar worker, and upper class.

Table 9 presents the ANOVA results for the impact of generational inequality on family status. There was a significant difference among the means $(\mathrm{F}=7.583, \mathrm{df}=4 / 219, \mathrm{p}>.05)$ at the .05 level. Scheffé Multiple Comparison Test (Table 10) shows that those who self-identify as poor and upper class perceive that their family status has impacted inequality through more at least one generation in their respective families.

Table 10: Scheffé Results of Generational Inequality by Family Status

\begin{tabular}{ccccccc}
\hline $\begin{array}{c}\text { Mean 1 } \\
\text { (Poor) }\end{array}$ & $\begin{array}{c}\text { Mean 2 } \\
\text { (Working Class) }\end{array}$ & $\begin{array}{c}\text { Mean 3 } \\
\text { (Middle Class) }\end{array}$ & $\begin{array}{c}\text { Mean 4 } \\
\text { (White Collar } \\
\text { Worker) }\end{array}$ & $\begin{array}{c}\text { Mean 5 } \\
\text { (Upper Class) }\end{array}$ & $\begin{array}{c}\text { Observed Mean } \\
\text { Differences }\end{array}$ & p \\
\hline 3.49 & 2.68 & & & & -.808 & $.002^{*}$ \\
3.49 & & 3.43 & & & -.747 & .005 \\
3.49 & & & 2.94 & -.258 & .854 \\
3.49 & & & & 3.86 & -1.175 & $.007 *$ \\
\hline
\end{tabular}

Table 11: Analysis of Variance Summary Table of the Impact of Illiteracy on Family Status

\begin{tabular}{ccrrrrr}
\hline & Source of Variance & Sum of Squares & df & Mean Square & F & Sig. \\
\hline \multirow{2}{*}{ Illiteracy } & Between Groups & 123.453 & 4 & 30.863 & 50.030 & $.000^{*}$ \\
& Within Groups & 132.633 & 215 & .617 & & \\
\hline
\end{tabular}

*Significant at the .05 Level

Similarly, ANOVA (Table 11) results reveal a statistical difference on the impact of illiteracy on family status $(\mathrm{F}=50.030, \mathrm{df}=4 / 219, \mathrm{p}>.05)$ at the .05 level.The Scheffé (Table 12) indicated that all community residents regardless of status indicated that they perceived their family status impacted whether someone in their family could not read or write. No other mean differences were observed. 
Table 12: Scheffé Results of Illiteracy by Family Status

\begin{tabular}{ccccccc}
\hline $\begin{array}{c}\text { Mean 1 } \\
\text { (Poor) }\end{array}$ & $\begin{array}{c}\text { Mean 2 } \\
\text { (Working Class) }\end{array}$ & $\begin{array}{c}\text { Mean 3 } \\
\text { (Middle Class) }\end{array}$ & $\begin{array}{c}\text { Mean 4 } \\
\text { (White Collar } \\
\text { Worker) }\end{array}$ & $\begin{array}{c}\text { Mean 5 } \\
\text { (Upper Class) }\end{array}$ & $\begin{array}{c}\text { Observed Mean } \\
\text { Differences }\end{array}$ & p \\
\hline 3.12 & 3.88 & & & & -1.900 & $.000^{*}$ \\
3.12 & & 5.02 & & & -1.852 & $.000^{*}$ \\
3.12 & & & 4.97 & 4.21 & -1.097 & $.000^{*}$ \\
\hline 3.12 & & & & & & \\
\hline
\end{tabular}

Table 13: Analysis of Variance Summary Table of the Impact of Technology on Family Status

\begin{tabular}{ccrrrrr}
\hline & Source of Variance & Sum of Squares & df & Mean Square & F & Sig. \\
\hline \multirow{2}{*}{ Technology } & Between Groups & 51.666 & 4 & 12.916 & 14.997 & $.000^{*}$ \\
& Within Groups & 184.316 & 214 & .861 & & \\
\hline
\end{tabular}

*Significant at the .05 Level

Table 13 also shows ANOVA results with a significant difference in the impact of technology on family status ( $\mathrm{F}=14.997, \mathrm{df}=4 / 219, \mathrm{p}>.05)$ at the .05 level. The Scheffé (Table 14 ) reveal that individuals who self-report as white collar and upper class perceive that family status has impacted their level of access to technology over their poor and middle class counterparts.

Table 14: Scheffé Results of Technology by Family Status

\begin{tabular}{ccccccc}
\hline $\begin{array}{c}\text { Mean 1 } \\
\text { (Poor) }\end{array}$ & $\begin{array}{c}\text { Mean 2 } \\
\text { (Working Class) }\end{array}$ & $\begin{array}{c}\text { Mean 3 } \\
\text { (Middle Class) }\end{array}$ & $\begin{array}{c}\text { Mean 4 } \\
\text { (White Collar } \\
\text { Worker) }\end{array}$ & $\begin{array}{c}\text { Mean 5 } \\
\text { (Upper Class) }\end{array}$ & $\begin{array}{c}\text { Observed Mean } \\
\text { Differences }\end{array}$ & p \\
\hline 3.16 & 2.63 & & & -.526 & .060 \\
3.16 & & 2.63 & & .006 & 1.000 \\
3.16 & & 3.94 & & $-1.309^{*}$ & $.000^{*}$ \\
3.16 & & & & 3.57 & $-.941^{*}$ & $.021^{*}$ \\
\hline
\end{tabular}

ANOVA results in Table 15 show a statistically significant difference among the means in regards to the impact of free or reduced lunch program on family status $(F=4.767, d f=4 / 219$, p>.05) at the .05 level. Scheffé reveals that individuals that self-reported as being middle class and white collar perceived that family status impacted whether their child participated in the free or reduced lunch program more than individuals that identified themselves as poor or upper class.

Lastly, Table 17 presents ANOVA results of the impact of a family's child attending a high poverty school $(\mathrm{F}=40.773, \mathrm{df}=4 / 219, \mathrm{p}>.05)$ at the .05 level. The final Scheffé results indicate that all the groups perceived that family status impacted whether or not their child attended a high poverty school regardless as to self-identification.

\section{DISCUSSION}

There were several noteworthy findings in the present study, the first of which pertains to the perceptions of community members regarding the impact of family status on personal wealth of the participants. Community residents' perceived family status as having been effective in increasing personal wealth for those who identify themselves as white collar more than individuals who self-identify in other categories. These views are consistent with those of Kaplan and Rauh (2013), Orfield and Lee (2005), and Author (2014). The aforementioned authors indicated that there is a relationship between individuals with higher levels of social 
statusand personal wealth. For the purpose of this study, personal wealth is identified as disposable income and personal savings.

Another finding is related to community residents who identified themselves as being upper class upper class perceived their family status impacted their level of income more than their poor, working class, middle class and white collar counterparts. These findings are aligned with those of George (2006), Belkhir, et al. (1994), Bonica, McCarty, Poole and Rosenthal (2013) and Nagrad and Nagrad (2014). The researchers indicate that individuals who identify as upper class are more likely to stay gainfully employed and utilize social connectionsto maintain their status. This phenomenon can be attributed to social networks of individuals of the upper classes being more effective in helping one to maintain social status.Moreover, individuals' social status can be more effective in driving one's level of income more than level of education.

The participants of the present study from all levels of family status indicated that family status was instrumental in increasing their levels of education. These findings were not consistent with those of Boundless (2016), Miller and Epstein (2011), Nagrad and Nagrad (2014), andRekker, et al. (2015). These authors posited that level of education is instrumental in guiding the family's level of income and family status. Likewise, individuals from all levels of family status perceived that it was instrumental lowering illiteracy in their family. These findings were in contrast with those of Stinson (2011) and Walters (2001) in that the lack of income and access to resources to the parents equals a lack of resources to the children making it more difficult to equally educate all children.

Another surprising finding of the present study are the results that participants who selfidentified as middle class are more likely than individuals who identified as poor, working class, white collar and upper class to perceive family status impacted their access to job opportunities.

An interesting finding revealed from the present study is related to generational inequality by family status. Respondents who self-identified as poor and upper class perceived that their family status was instrumental impacted whether inequality impacted them or their family for more than one generation over their middle class and white collar counterparts. Rivas-Drake, Hughes and Way (2009), Wiener and Pristoop (2006) and Rothstein (2014) indicate that social status has a lasting effect on whether or not families have equality in resources available to them.

Additionally, respondents who self-identified as upper class and middle class perceived that their family status was instrumental in increasing their level of access to technology. These findings parallel those of Kang (2016) and Zickuhr and Smith (2012) where parents who make less still have less access to technology in the form of the internet and computers. While the digital divide is lessening, it is still apparent to those who are in the lower levels of income stratification.

\section{References}

Author, D. H. (2014, May). Skills, education, and the rise of earnings inequality among the "other 99 percent."Science, 344(6186), 843-851.

Belkhir, J., Griffith, S., Beam, R., Carroll, D.,Carsombke, D., and Pulford, M. (1994). Multi-disciplinary reviews on race, sex \& class. Race, Sex \& Class, 2(1),7-30.

Bonica, A., McCarty, N., Poole, K., and Rosenthal, H. (2013). Why hasn't democracy slowed rising inequality?Journal of Economic Perspectives, 27(3): 103-24. 
Boundless. (2016, May). Weber's View of Stratification. Boundless Sociology.Retrieved from https://www.boundless.com/sociology/textbooks/boundless-sociology-textbook/global-stratification-andinequality-8/sociological-theories-and-global-inequality-72/weber-s-view-of-stratification-426-8944/

Cook, L. (2015, January 28). U.S. education: Still separate and unequal. U.S. News \& World Report. Retrieved from http://www.usnews.com/news/blogs/data-mine/2015/01/28/us-education-still-separate-and-unequal

George, D. (2006, December). Social class and social identity. ReviewofSocialEconomy, 64(4),429-445.

Hughes, D., Hagelskamp, C., Way, N., \& Foust, M.D. (2009). The role of mothers' and adolescents' perceptions of ethnic-racial socialization in shaping ethnic-racial identity among early adolescent boys and girls. Journal of Youth \& Adolescence, 38, 605-626.

Kang, C. (2016, February 22). Bridging a digital divide that leaves schoolchildren behind. New York Times. Accessed from: http://www.nytimes.com/2016/02/23/technology/fcc-internet-access-school.html?_r=0

Kaplan, S. N. and Rauh, J. (2013). It's the market: The broad-based rise in the return to top talent.Journal of Economic Perspectives, 27(3), 35-56.

Kozol, J. (2012). Fire in the ashes: Twenty-five years among the poorest children in America. New York: Crown Publishing Group.

Miller, R., \& Epstein, D. (2011, 5 July). There still be dragons: Racial disparity in school funding is no myth. Center for American Progress. Retrieved from http://www.americanprogress.org/issues/2011/07/still_be_dragons.html

Murnane, R. J. (2013). U.S. high school graduation rates: Patterns and explanations.Journal of Economic Literature, 51(2), 370-422.

Nagrad, L. and Nadrag, B. (2014, March). Socio-economic stratification. Economics, Management \& Financial Markets; 9(1), 362-379.

Oliff, P., \&Leachman, M. (2011). New school year brings steep cuts in state funding for schools. Retrieved from http://www.cbpp.org/files/9-1-11sfp.pdf

Orfied, G., and Lee, C. (2005). Why segregation matters: poverty and educational inequality. Cambridge, MA: The Civil Rights Project at Harvard University.

RekkerR,PardiniD,KeijsersL,BranjeS,LoeberR,MeeusW(2015)Movinginandoutof poverty:Thewithinindividualassociationbetweensocioeconomicstatusandjuveniledelinquency.PLoSONE10(11), 1-17.

Rivas-Drake, D., Hughes, D., \& Way, N. (2009). A preliminary analysis of associations among ethnic-racial socialization, ethnic discrimination, and ethnic identity among urban sixth graders. Journal of Research on Adolescence, 19, 558-584.

Wiener, R., and Pristoop, E. (2006).How states shortchange the districts that need the most help: The funding gap. Washington, DC: The Education Trust.

Rothstein, R. (2014).The racial achievement gap, segregated schools, and segregated neighborhoods - a constitutional insult. Race and Social Problems, 6(4). Retrieved from http://www.epi.org/publication/the-racialachievement-gap-segregated-schools-and-segregated-neighborhoods-a-constitutional-insult/

Stinson, D. W. (2011). When the "burden of acting White" is not a burden: School success and African American male students. Urban Review, 43, 43-65.

Walters, B. P. (2001). Access and the state: Historical continuities and discontinuities in racial inequality in American education. Sociology of Education. 74, 35 - 49.

Willhelm,S.(1970).WhoneedstheNegro?NewYork;Doubleday, pp. 65.

Willhelm,S.(1983).BlackinwhiteAmerica.Boston:Schenkman.

Zickuhr, K., and Smith, A. (2012). Digital differences: While increased internet adoption and the rise of mobile connectivity have reduced many gaps in technology access over the past decade, for some groups digital disparities still remain. Pew Research Center's Internet \& American Life Project.

http://www.pewinternet.org/files/old-media/Files/Reports/2012/PIP_Digital_differences_041312.pdf 